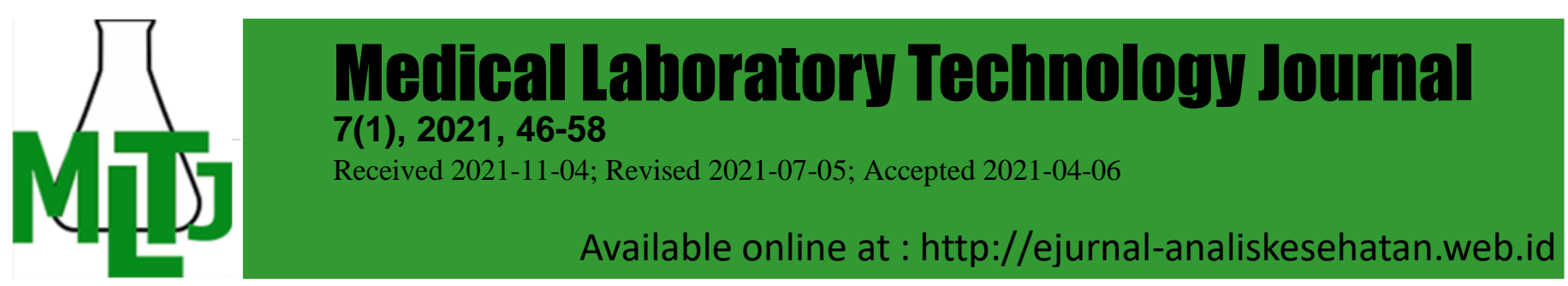

\title{
MiR-21 and mRNA PTEN Expression Levels and Biomarker Potential in Breast Cancer
}

\author{
Dinna Rakhmina ${ }^{1 *}$, Sofia Mubarika Haryana ${ }^{2}$, Teguh Aryandono ${ }^{3}$ \\ ${ }^{1}$ Medical Laboratory Technology Poltekkes Kemenkes Banjarmasin, ${ }^{2}$ Department of \\ Histology and Cell Biology, Faculty of Medicine, Universitas Gadjah Mada, \\ ${ }^{3}$ Departement of Surgery, Faculty of Medicine, Universitas Gadjah Mada/Sardjito \\ Hospital Yogyakarta. *Email: dinnapoltekesbjm@gmail.com \\ DOI: $10.31964 / \mathrm{mltj} . v 7 i 1.364$
}

\begin{abstract}
MiR-21 has been linked to tumorigenesis, development, and metastasis in tumor pathogenesis. All human cancers, including breast cancer, have increased expression of MiR-21, which is the only miRNA that has increased expression. PTEN expression was found to be reduced in the majority of solid tumors, including breast cancer. Since lymph node metastatic factors, estrogen receptor status, tumor grade, and tumor node metastasis (TNM) all decreased PTEN expression, the PTEN expression profile may be a very useful prognostic marker in breast cancer. PTEN inhibits PIP3 (phosphatidylinositol 3,4,5-triphosphate) activity by having protein phosphatase and lipid phosphatase activity that is the polar opposite of PI3K (Phosphatidyl Inositol 3-Kinase). The aim of this research was to see how often miR-21 and mRNA PTEN were expressed at different stages of breast cancer and whether they could be used as prognostic markers. This type of research is an observational study with a cross-sectional design. The sample size of 43 people came from breast cancer patients. Analysis of miR-21 expression and mRNA PTEN using Real-Time qPCR. The results showed that miR-21 expression increased 1.32 times at an advanced stage compared to an early stage, while mRNA PTEN expression decreased 1.33 fold at an advanced stage compared to an early stage. According to the findings, miR-21 expression in the blood plasma of breast cancer patients was upregulated at an advanced stage compared to an early stage and downregulated mRNA PTEN expression. MiR-21 which is increased at an advanced stage has the potential to be a poor prognostic marker at the stage of breast cancer. The change in miR-21 expression can be a good candidate as a molecular prognostic marker and for future research the role of miR-21 in breast cancer progression will further enrich the scientific repertoire, especially in the health and clinical fields.
\end{abstract}

Keywords: MiR-21; mRNA PTEN; Real-Time qPCR

\section{INTRODUCTION}

Breast cancer is a complicated condition with a wide range of genetic changes. Breast cancer is the world's leading cause of death. In 2020, 2.3 million people will be diagnosed with breast cancer worldwide, with 685,000 deaths, and 7.8 million women will have been diagnosed with breast cancer in the previous five years, making it the most common cancer in the world. Breast cancer ranked first among the top five cancers in Indonesia in the same year, with 65,858 (16.6 percent) deaths, a mortality rate of 22,430 (9.6\%), and a 5-year prevalence of 201,143 cases (per 100,000) (WHO, 2020).

Corresponding Author: Dinna Rakhmina

Medical Laboratory Technology Poltekkes Kemenkes Banjarmasin.

Mistar Cokrokusumo Street 4a Banjarbaru Indonesia

Email: dinnapoltekesbjm @gmail.com 
Currently, over several hundred micro RNA (miRNA) have been discovered, and variations in miRNA expression have been linked to several cancers, so miRNA profiles are used to diagnose or prognosis some cancers, as well as to distinguish certain forms of cancer (Yan et al., 2008). MicroRNA modulates gene expression, making it a potential diagnostic and prognostic predictor as well as a therapeutic target (Heneghan et al., 2010). As a result, miRNA is a promising new cancer biomarker in the future (Anwar et al., 2020; Mo et al., 2012)

There has been a decrease in miRNA expression in cancerous tissue relative to normal tissue, according to several reports. This means that miRNA can be used to reflect a clinical condition as well as a prognostic indicator. Breast cancer patients' prognosis may be determined by tumor size, histological rating, and the presence of lymph nodes or metastases, so that molecular features can be used to reliably assess the increased risk of death or survival in the current malignancy management (Yan et al., 2008).

Lowery et al. (2009) was the first to show that circulating miRNA can be found in cell-free body fluids including plasma and serum. The ability to repeat measurements in a non-invasive way, as well as excellent stability in plasma / serum, where they can circulate even beyond the exosome and are stable due to binding to the Argonaute protein, are all significant advantages of circulating miRNA (Arroyo et al., 2011; Mitchell et al., 2008; Turchinovich et al., 2011).

All human cancers, including breast cancer, have increased expression of MiR21, which is the only miRNA that has increased expression (Negrini \& Calin, 2008). MiR21 has been linked to tumorigenesis, development, and metastasis in tumor pathogenesis. Furthermore, miR-21 expression levels are linked to clinical pathologic factors and cancer patient prognosis, suggesting that miR-21 may be used as a prognostic marker in humans (Anwar et al., 2019; Pan et al., 2010).

PTEN (Phosphatase Tensin and Homolog) is a tumor suppressor gene that has been shown to be missing or mutated in a number of human cancers. PTEN expression was found to be reduced in the majority of solid tumors. PTEN expression decreases in relation to lymph node metastatic factors, estrogen receptor status, tumor grade, and tumor node metastasis (TNM), according to several studies, suggesting that the PTEN expression profile may be a very useful prognostic marker in breast cancer (Huang et al., 2009). PTEN inhibits PIP3 (phosphatidylinositol 3,4,5-triphosphate) activity by having protein phosphatase and lipid phosphatase activity that is the polar opposite of PI3K (Phosphatidyl Inositol 3-Kinase) activity (Song et al., 2012).

In Wickramasinghe et al., (2009) study, a decrease in miR21 mediated by estrogen was linked to an increase in the expression of the PTEN protein in breast cancer cells. Meanwhile, according to Schwarzenbach et al., (2012), PTEN expression is less important in determining prognosis in breast cancer, but this is still debatable. PTEN expression has been linked to a poor prognosis in certain studies, whereas it has not been linked to a bad prognosis in others.

The difference in the results of several studies related to the expression of mir21 and PTEN in breast cancer became the basis for this study. This research aims to determine the level of miR-21 and mRNA PTEN expression in patient serum, and expected to be a good candidate as a molecular prognostic. 


\section{MATERIALS AND METHOD}

An observational study with a prevalence study research design is what this sort of study is (cross-sectional study). A total of 43 serum samples were taken from female patients between the ages of 30 and 70 who had been clinically diagnosed with breast cancer but had not received treatment. The patient came from RSUP Dr. Sardjito Yogyakarta. This research has been submitted to the Ethics Commission with the reference number KE / FK / 60 / EC. The table below shows the primer sequences used in this analysis.

Table 1. Target Sequences from Specified Genes

\begin{tabular}{lr}
\hline \multicolumn{1}{c}{ Genes } & Target Sequences \\
\hline hsa-miR-21-5p & UAGCUUAUCAGACUGAUGUUGA \\
hsa-miR-16-5p & UAGCAGCACGUAAAUAUGGCG \\
PTEN & \\
Forward & 5'-GGGTCTGAGTCGCCTGTC-3' \\
Reverse & 5'-CCGTGTAGGCAGTAGAAG-3' \\
$\beta$-Actin & \\
Forward & 5'-GGGAATTCAAAACTGGAACGGTGAAGG-3' \\
Reverse & 5'-GGAAGCTTATCAAAGTCCTCGGCCACA-3' \\
\hline
\end{tabular}

\section{Extraction of RNA and synthesis of CDNA}

The miRCURYTM RNA Isolation Kit was used to remove total RNA from the blood plasma of breast cancer patients (Exiqon Inc, USA). Exiqon's protocol is used for the RNA extraction. Furthermore, the kit miRCURY LNA® Universal RT microRNA PCR Polyadenylation and CDNA synthesis was used for cDNA synthesis (Exiqon Inc, USA). Each PCR reaction for CDNA synthesis had a total volume of $20 \mu \mathrm{L}$, which included nuclease-free water, 10x enzyme mix, $5 x$ reaction buffer, and RNA spike-in template (UniSP6). The PCR was performed by incubating the samples at $42^{\circ} \mathrm{C}$ for 60 minutes and then inactivating the reverse transcriptase at $95^{\circ} \mathrm{C}$ for 5 minutes. Furthermore, before it is used for further analysis, the synthesized cDNA is deposited at $4^{\circ} \mathrm{C}$.

\section{Real-Time Quantitative Polymerase Chain Reaction (Real-Time qPCR)}

The process two-step Real-Time qPCR was used to examine miR-21 expression. Real-Time qPCR was used to detect expression 21 microRNA (CFX96Touch ${ }^{\text {TM }}$ RT-PCR, Bio-Rad Laboratories, Inc, California, US). The package miRCURY LNA Universal RT microRNA PCR, SYBR Green master mix (Exiqon Inc, USA) was used to amplify microRNA-21. Primary miR-21 (HSA-miR-21), primary miR-16 as a reference gene, and $\mathrm{H}_{2} \mathrm{O}$ as a negative control were used in the PCR reaction. SYBR ${ }^{\circledR}$ Green, PCR primer mix, and cDNA template were used in a total of $10 \mu \mathrm{L}$ PCR reactions per tube (Exiqon Inc, USA). Initial denaturation stages of 10 minutes at $95^{\circ} \mathrm{C}$, denaturation for 10 seconds at $95^{\circ} \mathrm{C}$, annealing for 1 minute at $58^{\circ} \mathrm{C}$, and extension for 5 seconds at $60^{\circ} \mathrm{C}$ were used in the PCR. The stage final extension at $60^{\circ} \mathrm{C}$ for 5 seconds preceded the end of the loop. Biorad CFX Manager ${ }^{\mathrm{TM}}$ Software was used to conduct the analyses.

The single-method stage Real-Time qPCR was used to analyze miR-21 expression. mRNA PTEN expression was detected using Real-Time qPCR (CFX96 


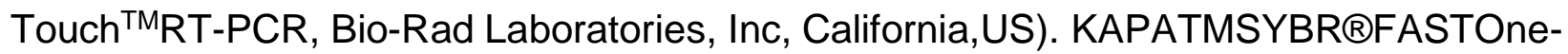
Step qRT-PCR Kit was used to amplify PTEN mRNA. Forward and reverse PTEN mRNA (hsa-mRNA PTEN) primers, -actin primers as a reference gene, and $\mathrm{H}_{2} \mathrm{O}$ as a negative control were used in the PCR reaction. KAPA SYBR®FAST qPCR Master Mix, forward primer, reverse primer, dUTP, KAPA RT Mix, RNA prototype, nuclease-free water make up a total of $10 \mu \mathrm{L}$ PCR reactions per channel. Initial denaturation stages of 3 minutes at $95^{\circ} \mathrm{C}$, denaturation for 10 seconds at $95^{\circ} \mathrm{C}$, annealing for 30 seconds at $64^{\circ} \mathrm{C}$, and extension for 5 seconds at $60^{\circ} \mathrm{C}$ were used in the PCR. The final extension stage at $60^{\circ} \mathrm{C}$ for 5 seconds preceded the end of the cycle. Biorad CFX Manager ${ }^{\mathrm{TM}}$ Software was used to conduct the analyses.

\section{RESULTS AND DISCUSSION}

\section{Real-Time qPCR analysis of miR-21 and mRNA PTEN}

The Biorad CFX Manager ${ }^{\mathrm{TM}}$ Software was used to perform Real-Time qPCR quantification analysis of miR-21 expression and mRNA PTEN. In blood plasma samples from breast cancer patients, amplification data from miR-21 as a target and miR-16 as a reference gene, as well as mRNA PTEN as a target and $\beta$-actin as a reference gene, were acquired based on Real-Time qPCR results.

In Real-Time qPCR, the quantity of amplicon is measured after the amplification cycle of each sample ends. The number of amplicons increased with increasing fluorescence signal. The average amplification cycles for miR-16 and miR-21 were 26.88 and 27.04, while those for -actin and mRNA PTEN were 31.00 and 32.75 , respectively. The miR-21 and mRNA PTEN amplification curves are shown in Figure 1.
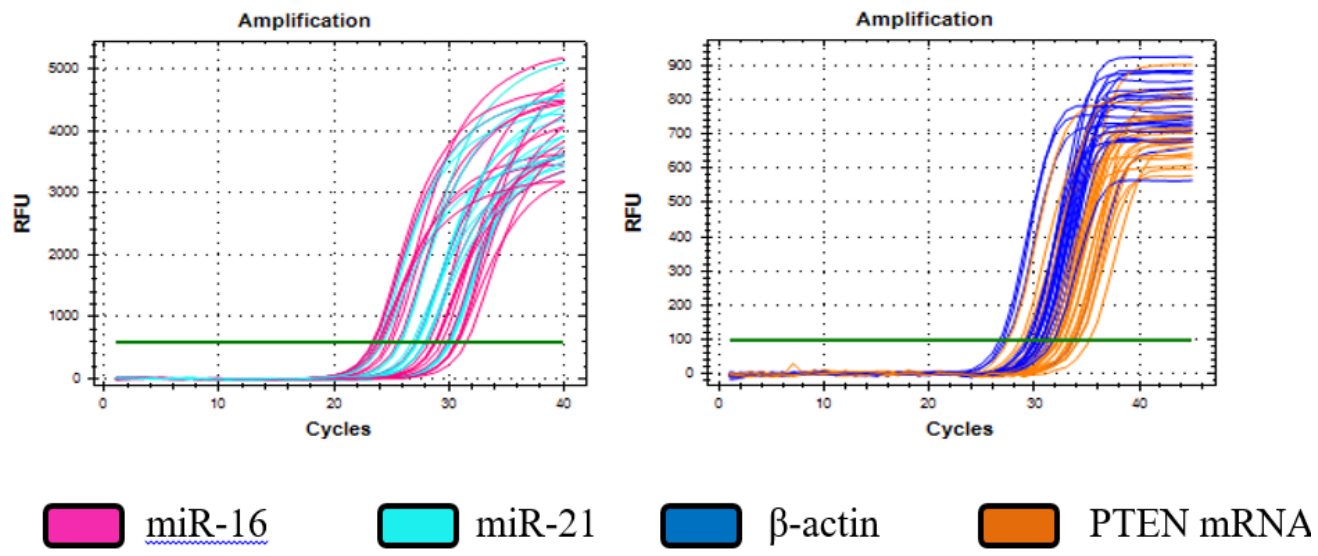

Figure 1. Real-Time qPCR amplification curves for miR-21 and mRNA PTEN

\section{Specificity of Real-Time qPCR}

Melting curve in Real Time qPCR reaction shows the dissociation characteristics of dsDNA during heating. As the temperature increases, the template dissociates as the absorbance intensity increases. The results of the melting curve analysis showed that miR-21 and mRNA PTEN were amplified which was characterized by an increase in the value of RFU (relative fluorescence unit). The RFU is formed from the luminescence of SYBR green as the template amplification reaction increases. The optimum melting temperature values for miR-21 were $67.5^{\circ} \mathrm{C}-68.5^{\circ} \mathrm{C}$ and $69.5^{\circ} \mathrm{C}-70^{\circ} \mathrm{C}$ for miR-16 (reference gene), while the optimum melting temperature for PTEN mRNA was $81^{\circ} \mathrm{C}-$ 
$81.5^{\circ} \mathrm{C}$ and for $\beta$-actin (reference gene) it is $79.5^{\circ} \mathrm{C}-80^{\circ} \mathrm{C}$ (Figure 2).
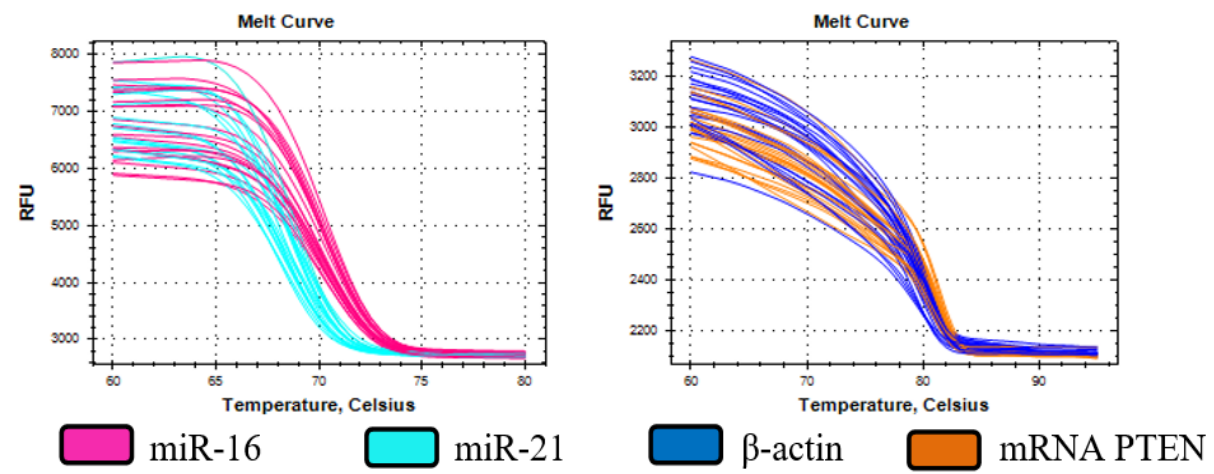

Figure 2. Melt Curve Analysis of the Expression of miR-21 and mRNA PTEN

Specificity and detection of contamination in real time PCR reactions can be identified through a specific melt peak curve at a certain temperature range. Double strand DNA (dsDNA) dissociation, which only produces particular melt peaks depending on the type of primer used, can be discovered via melt curve and melt peak analysis (Figure 3).
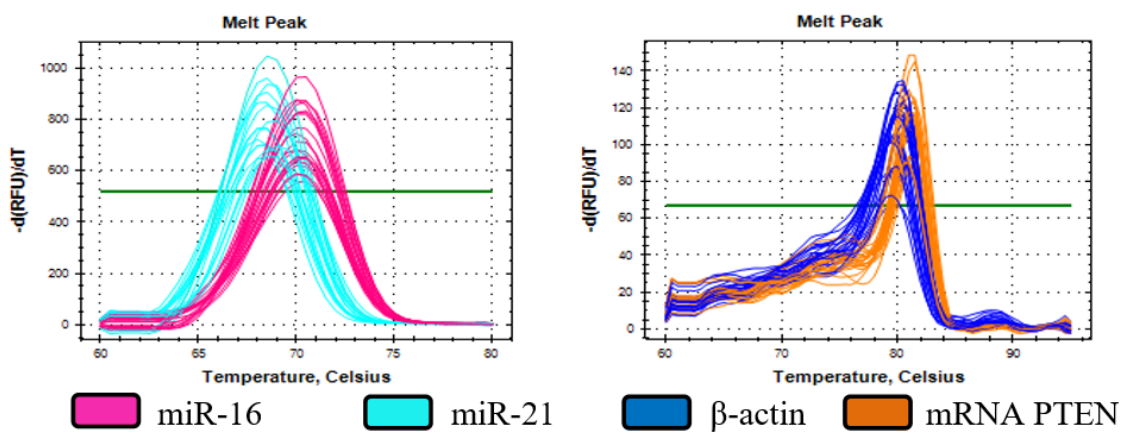

Figure 3. Melt Peak Analysis of the Expression of miR-21 and mRNA PTEN

\section{Expression of miR-21 and mRNA PTEN at Early and Advanced Stage}

The threshold cycle $(\mathrm{Ct})$ value is a PCR cycle where the fluorescence signal from the dye reporter passes the threshold threshold. The numerical value of $\mathrm{Ct}$ is inversely proportional to the number of amplicons in the reaction i.e., the lower the $\mathrm{Ct}$ value the greater the number of amplicons. Data were analyzed by comparative Ct method or better known as $2^{-\Delta \Delta C t}$. The use of the comparative Ct method is very easy and is able to present data in the form of fold changes as a determinant for the expression level of the examined gene. The form of the equation fold change $\left(2^{-\Delta \Delta C t}\right)$ is used to compare the gene expression of two different samples and each sample examined must be linked to its internal control gene, namely the reference gene. Ct calculations illustrate the comparison of expression between miR-21 in early and advanced stages or mRNA PTEN expression in early and advanced stages. If the Ct result is positive (+), it indicates that miR-21 or mRNA PTEN has decreased expression (downregulated). If CT is negative (-), it means that the expression of miR-21 or mRNA PTEN has risen (up-regulated). If the fold change calculation gives a result greater than one, the gene is up-regulated.

Table 1 shows the expression of miR-21 and mRNA PTEN in terms of advanced 
and early stages. The fold change value of miR-21 in the advanced stage increased (upregulated) 1.32-fold compared to the early stage, while the fold-change value of mRNA PTEN in the advanced stage decreased (down-regulated) 1.33-fold compared to the early stage. Figure 4 shows the fold change of miR-21 expression and mRNA PTEN in the advanced and early stages.

Table 2. Fold Change in miR-21 and mRNA PTEN Expression was Determined Based on Stage of the Patients

\begin{tabular}{|c|c|c|c|}
\hline Variable & $\Delta \mathrm{Ct}^{*}$ & Fold change & $P$ value \\
\hline $\begin{array}{c}\text { miR-21 } \\
\text { Advanced Stage } \\
\text { Early Stage }\end{array}$ & $\begin{array}{l}0.04 \\
0.43\end{array}$ & $\begin{array}{c}1.32 \\
\text { (upregulated) }\end{array}$ & 0.264 \\
\hline $\begin{array}{l}\text { PTEN mRNA } \\
\text { Advanced Stage } \\
\text { Early Stage }\end{array}$ & $\begin{array}{l}1.84 \\
1.43\end{array}$ & $\begin{array}{c}1.33 \\
\text { (downregulated) }\end{array}$ & 0.416 \\
\hline
\end{tabular}

$\Delta \mathrm{Ct}$ : The value of $\mathrm{Ct}$ is inversely proportional to the relative expression level; if $\mathrm{Ct}$ is higher, the value of expression is lower, and vice versa

a.
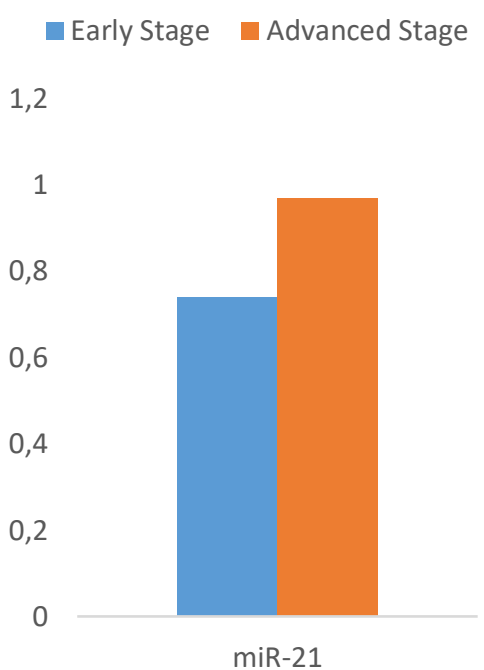

b. Early Stage Advanced Stage

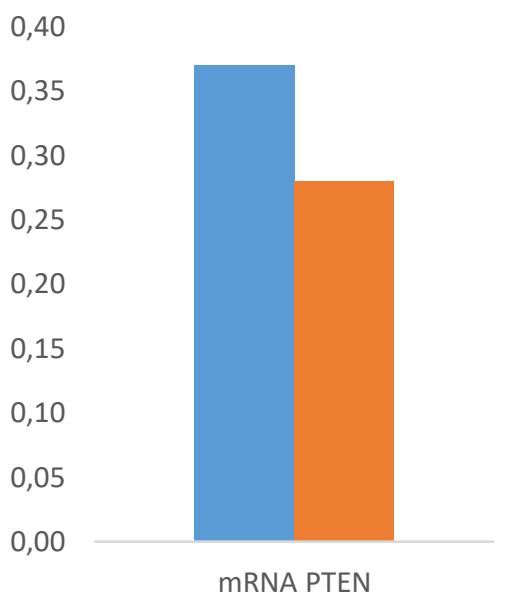

Figure 4. a. The Value of Fold Change miR-21 at an Early Stage and an Advanced Stage, b. The Value of Fold Change PTEN mRNA at an Early Stage and an Advanced Stage

\section{Expression of miR-21 and mRNA PTEN Based on Molecular Characteristics}

Based on hormone receptors, in ER(-), miR-21 expression was 1.14 times lower (downregulated) than in $\mathrm{ER}(+)$, and the same thing happened in $\mathrm{PR}(-)$, where miR-21 expression was 1.63 times lower (downregulated) than in PR(+). Expression of miR-21 in HER2 (+) increase (up-regulated) 1.38 times compared to HER2 (-). Meanwhile, mRNA PTEN expression at ER(-), increased 1.96 times compared to $\mathrm{ER}(+)$ and the same thing 
happened to $\mathrm{PR}(-)$ with an increase of 2.02 times compared to $\mathrm{PR}(+)$. mRNA PTEN expression in HER2(+) increased 1.60 times compared to HER2(-).Table 2 and Figure 5 illustrate MiR-21 and mRNA PTEN expression in terms of ER, PR, and HER2 status.

Table 3. The Status of ER, PR, Her2 Showed a Fold Change in miR-21 and PTEN mRNA

\begin{tabular}{|c|c|c|c|c|c|c|}
\hline \multirow[t]{2}{*}{ Variabel } & \multicolumn{2}{|c|}{$\Delta \mathrm{C}_{\mathrm{t}}$} & \multicolumn{2}{|c|}{ Fold change } & \multicolumn{2}{|c|}{$P$ value } \\
\hline & $\begin{array}{l}\text { miR- } \\
21\end{array}$ & $\begin{array}{l}\text { PTEN } \\
\text { mRNA }\end{array}$ & miR-21 & $\begin{array}{l}\text { PTEN } \\
\text { mRNA }\end{array}$ & $\begin{array}{c}\mathrm{miR}- \\
21\end{array}$ & $\begin{array}{l}\text { PTEN } \\
\text { mRNA }\end{array}$ \\
\hline Reseptor & & & 1,14 & 1,96 & 0,712 & 0,146 \\
\hline Estrogen & & & (downregula & (upregula & & \\
\hline ER - & 0,36 & 1,43 & ted) & ted) & & \\
\hline ER + & 0,18 & 2,40 & & & & \\
\hline $\begin{array}{l}\text { Reseptor } \\
\text { Progesteron }\end{array}$ & & & $\begin{array}{c}1,63 \\
\text { (downregula }\end{array}$ & $\begin{array}{c}2,02 \\
\text { (upregula }\end{array}$ & 0,444 & 0,125 \\
\hline $\begin{array}{l}\mathrm{PR}- \\
\mathrm{PR}+\end{array}$ & $\begin{array}{r}0,59 \\
-0,11\end{array}$ & $\begin{array}{l}1,49 \\
2,50\end{array}$ & ted) & ted) & & \\
\hline Her-2 & & & 1,38 & 1,60 & 0,968 & 0,449 \\
\hline Positif & $-0,01$ & 1,49 & (up & (upregula & & \\
\hline Negatif & 0,46 & 2,17 & regulated) & ted) & & \\
\hline
\end{tabular}
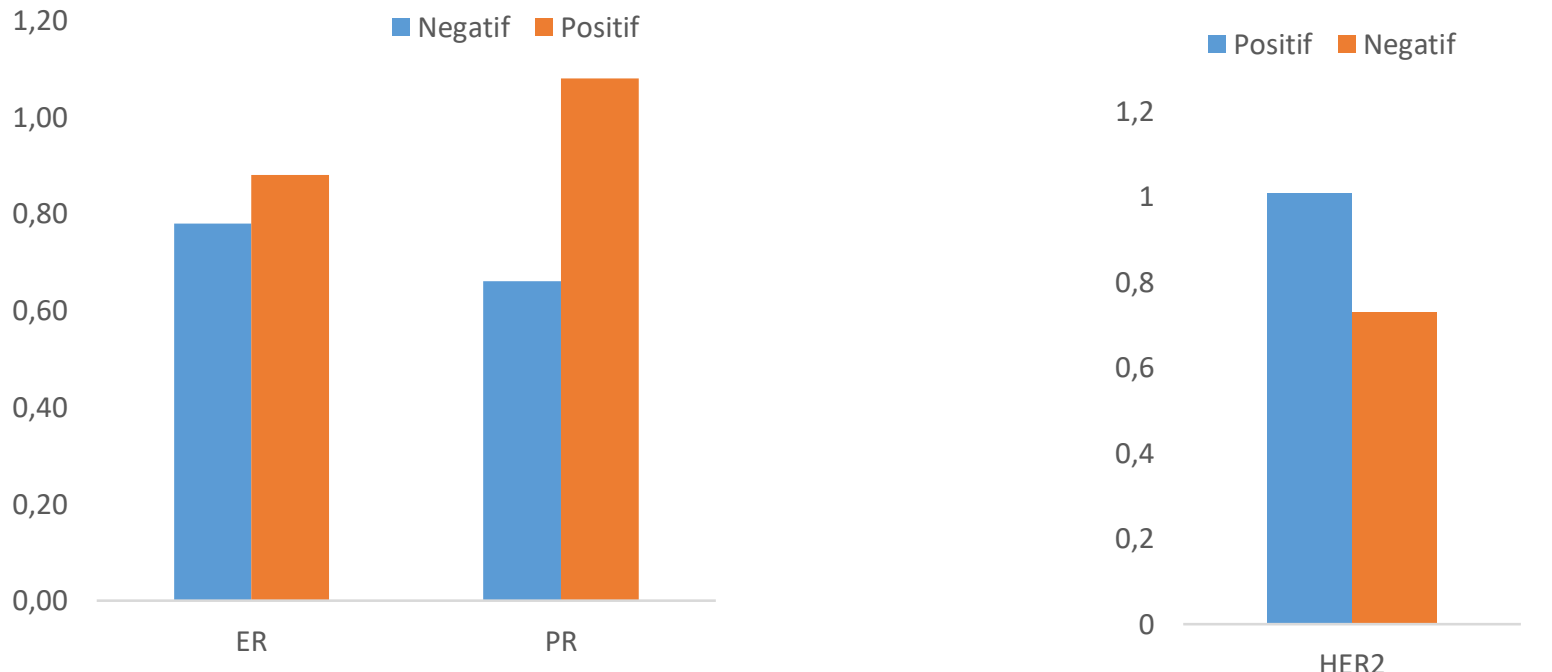

Figure 5a. Fold Change on miR-21 Seen from the Status of ER, PR, Her2 

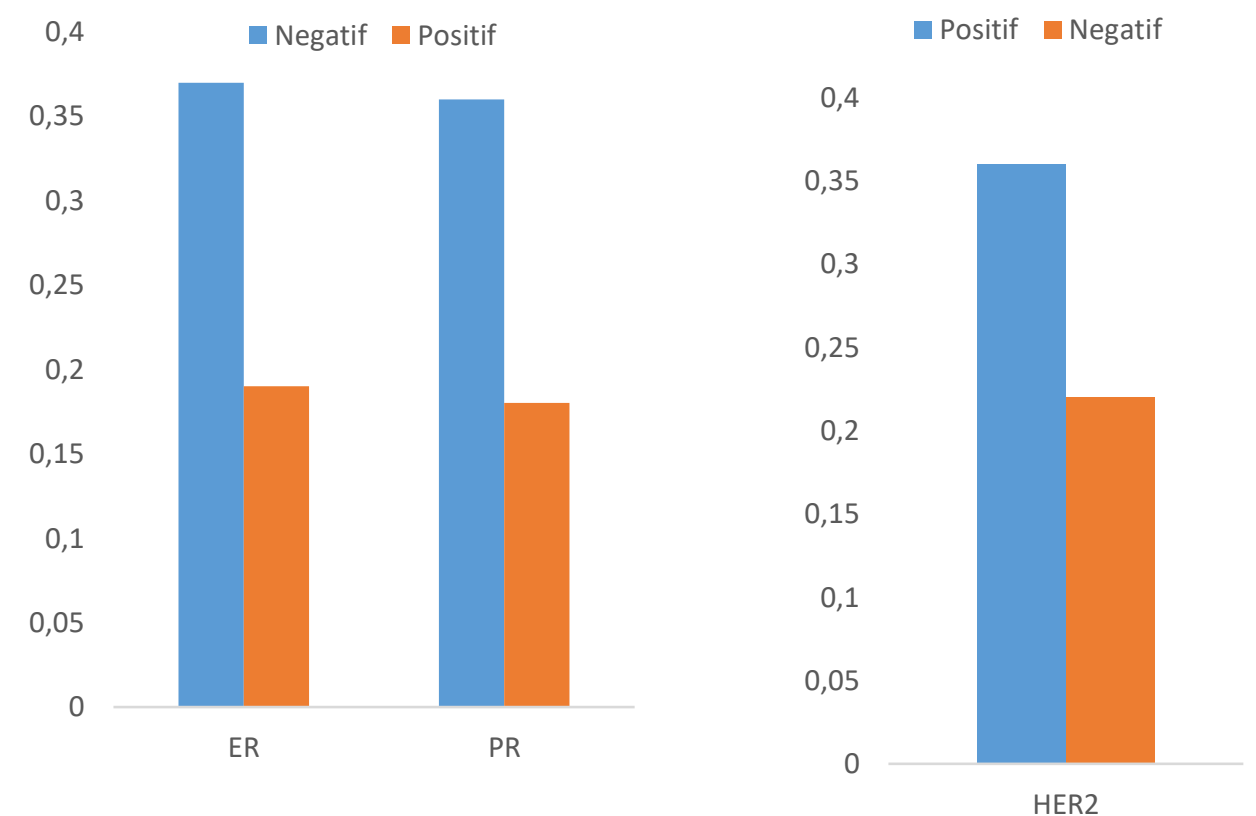

Figure 5b. Fold Change on mRNA PTEN Seen from the Status of ER, PR, Her2

Table 3, the fold change value of miR-21 expression when compared between the luminal $A$ subtype and other subtypes, the results of the fold change luminal $A$ vs luminal $B$ decreased (downregulated) 1.32 times, luminal A vs Her2 overexpression decreased (downregulated) 1.18 times, luminal $A$ vs triple negative increased (up-regulated) 1.45 times. mRNA PTEN expression when viewed from the luminal A subtype vs other subtypes, the results of mRNA PTEN expression in luminal $A$ vs luminal $B$ decreased (downregulated) 1.82 times, luminal $A$ vs Her2 overexpression decreased (downregulated) 3.12 times, luminal A vs triple negative decreased (downregulated) 2.44 times. In addition, miR-21 and mRNA PTEN expression in terms of the status of breast cancer subtypes can be seen in the form of a diagram as shown in Figure 6.

Table 4. The Satus of Breast Cancer Subtypes Showed a Fold Change in miR-21 and mRNA PTEN

\begin{tabular}{|c|c|c|c|c|c|c|}
\hline \multirow[b]{2}{*}{ Variabel } & \multicolumn{2}{|c|}{$\Delta \mathrm{C}_{T^{*}}^{*}$} & \multicolumn{2}{|c|}{ Fold change } & \multicolumn{2}{|c|}{$P$ value } \\
\hline & $\begin{array}{c}\text { miR- } \\
21\end{array}$ & $\begin{array}{l}\text { PTEN } \\
\text { mRNA }\end{array}$ & miR-21 & $\begin{array}{l}\text { PTEN } \\
\text { mRNA }\end{array}$ & $\begin{array}{c}\mathrm{miR}- \\
21\end{array}$ & $\begin{array}{l}\text { PTEN } \\
\text { mRNA }\end{array}$ \\
\hline Luminal A & 0,18 & 2,86 & 1,32 & 1,82 & & \\
\hline Luminal B & $-0,22$ & 2,01 & $\begin{array}{l}\text { (downregu } \\
\text { lated) }\end{array}$ & $\begin{array}{l}\text { (downregu } \\
\text { lated) }\end{array}$ & 0,729 & 0,300 \\
\hline Luminal A & 0,18 & 2,86 & 1,18 & 3,12 & & \\
\hline Her2 Overexpression & $-0,66$ & 1,21 & $\begin{array}{c}\text { (downregu } \\
\text { lated) }\end{array}$ & $\begin{array}{c}\text { (downregu } \\
\text { lated) }\end{array}$ & & \\
\hline Luminal A & 0,18 & 2,86 & 1,45 & 2,44 & & \\
\hline Triple Negative & 0,72 & 1,57 & $\begin{array}{l}\text { (up- } \\
\text { requlated) }\end{array}$ & $\begin{array}{l}\text { (downregu } \\
\text { lated) }\end{array}$ & & \\
\hline
\end{tabular}




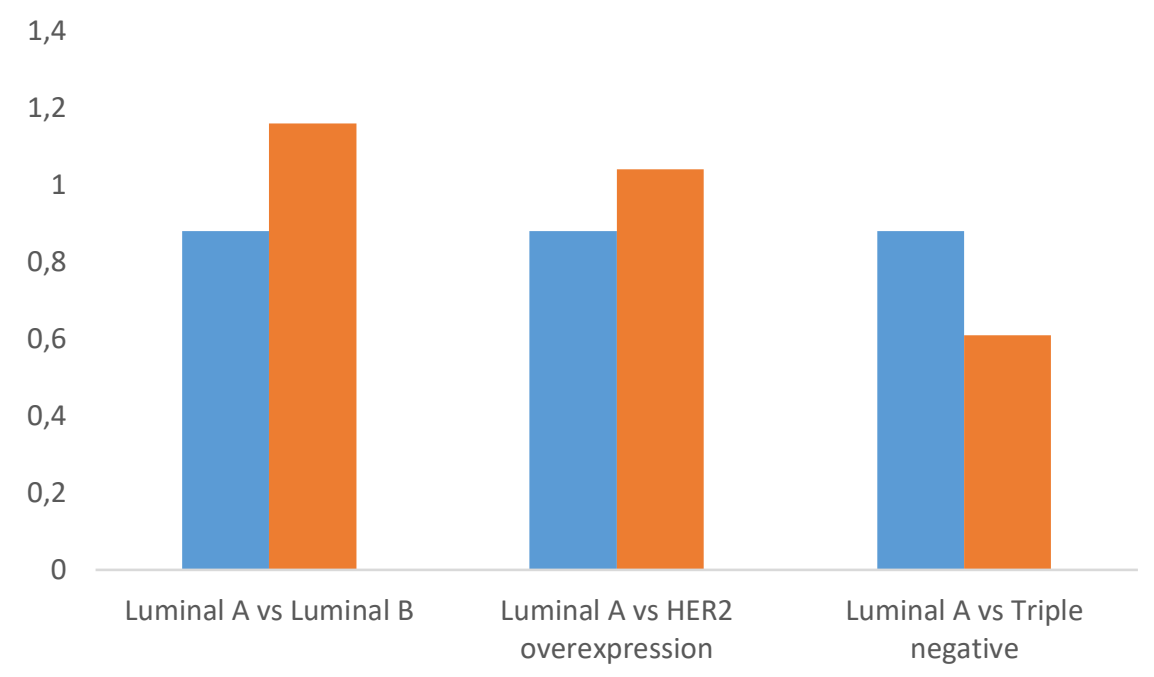

Figure 6a. The Status of Breast Cancer Subtypes Showed a Fold Change in miR-21

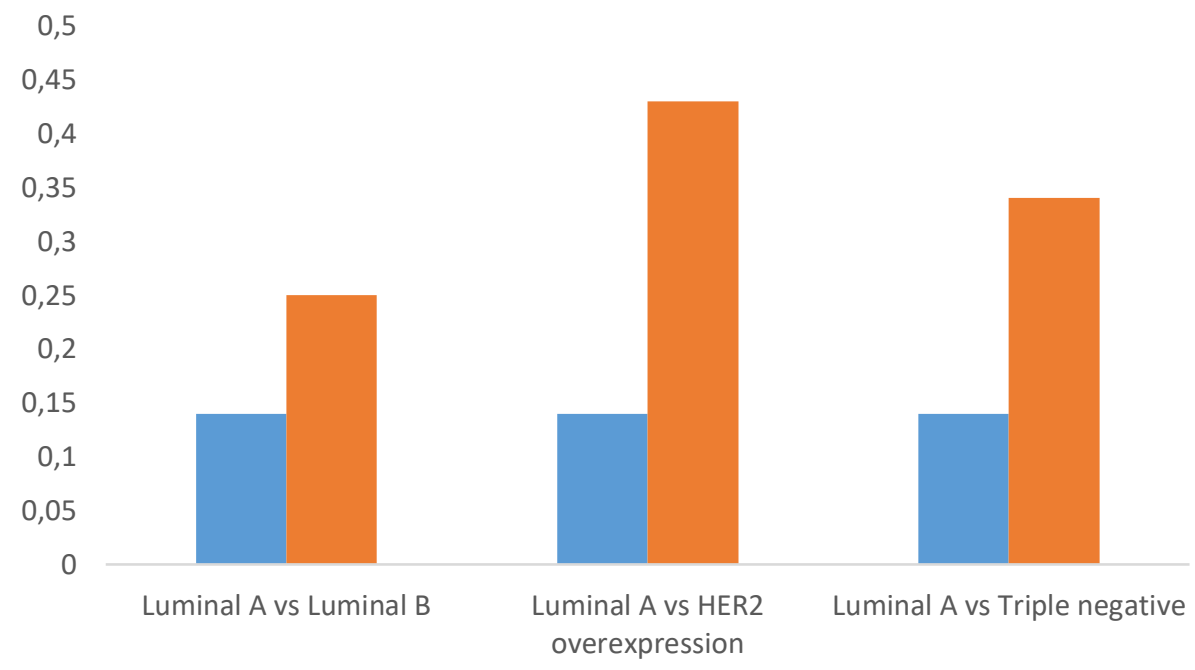

Figure 6b. The Status of Breast Cancer Subtypes Showed a Fold Change in PTEN mRNA

MiR-21 expression was up-regulated 1.32 times more in the advanced stage than in the early stage, according to the findings. This demonstrates that miR-21 is an oncogene that can promote tumor cell growth while also inhibiting apoptosis. Other studies have shown that miR-21 is up-regulated in advanced stage (III / IV) breast cancer tissue relative to early stage (I / II) breast cancer tissue (M. Li et al., 2010). Overexpression of miR-21 is thought to play a role in cell proliferation, migration, and invasion (Meng et al., 2007). Several other studies have shown that miR-21 expression 
is upregulated in a variety of cancers. In gastric cancer tissue, MiR-21 expression was higher than in non-tumor tissue. Furthermore, miR-21 was found to be overexpressed in patients with non-small cell lung cancer (NSCLC) (Zhang et al., 2010). Another research found that the expression of mir-21 in plasma was substantially associated with miR-21 expression in tumor tissue in hepatocellular carcinoma (HCC). There have also been some functional experiments on miR-21 to show that it has oncogenic activity (Chan et al., 2005).

PTEN is a tumor suppressor gene with phosphatase activity that is mutated in a variety of cancers, including breast cancer. PTEN protein expression was decreased by $38 \%$ in invasive cancer and $11 \%$ in in situ cancer in breast cancer. In stage II and stage III breast cancer, the frequency of PTEN expression decreases dramatically. Expression in ductal carcinoma in situ appears to represent the expression pattern of the invasive component in tumors with an in situ or invasive component. PTEN expression is downregulated in advanced breast cancer, according to these findings. This is supported by this research, which found that the expression of mRNA PTEN in plasma was lower in advanced breast cancer than in early stage breast cancer (Li et al., 2012).

Regulation of MiR-21 has steadily increased breast cancer invasion and the growth of malignant cancer cells. Anti miR-21 research has also confirmed the relationship between miR-21 and PTEN (Li et al., 2012; Meng et al., 2007). As anti miR-21 inhibits miR-21 expression, PTEN is expressed, which inhibits Akt phosphorylation, activating p21 / WAF1 / CIP1 and p27 / KIP1, as well as Bad defosphorylation, resulting in resistance to the G1 / S phase of the cell cycle and triggering apoptosis (Andorfer et al., 2011).

MiR-21 expression increased in ER+, PR+, and HER2+ based on Real Time qPCR study. The findings of this study are in line with those of Radojicic et al.(2011), who discovered that miR-21, which is involved in cell development, angiogenesis, proliferation, and invasion, is overexpressed in breast cancer. In breast cancer cells, stimulation of HER2 signals upregulates miR-21 expression through the MAPK (ERK1 / 2) pathway. The activation of MiR-21 by HER2 overexpression will lead to cancer cell invasion and metastasis (Huang et al, 2009). Hormone receptors (HR) are expressed in about half of breast cancers that overexpress HER2 (Prat et al, 2008). In malignant breast tumors, the presence of positive hormone receptors $(\mathrm{HR}+/ \mathrm{HER} 2+$ causes cell proliferation and survival.

When compared to other breast cancer subtypes, the luminal B subtype had the highest miR-21 expression. ER+ breast cancer with increased proliferation was identified as subtype luminal B breast cancer in several studies (Cheang et al., 2009). Increased expression of the PI3K gene pathway is a major feature of luminal B breast cancer, according to a preclinical report, and the inhibition of growth induced by endocrine therapy in the luminal $B$ breast cancer cell line can be significantly increased by adding selective PI3K inhibitors, suggesting that PI3K inhibitors may play a role (Tran \& Bedard, 2011).

The use of plasma samples as an alternative option in non-invasive molecular examinations can be inferred based on the findings of this study because the miRNA and mRNA expression patterns are close to those found in breast cancer tissue. Upregulated miR-21 expression was found to be oncomer, while downregulated PTEN mRNA expression was found to be tumor suppressor, implying that this change in expression is essential in the development and progression of breast cancer cells. Since one miRNA can target several genes and different miRNAs can target the same gene, it's likely that 
miR-21 expression rises as a result of its ability to block gene panels that control cell proliferation and apoptosis, according to the biogenesis theory of miRNA. MiR-21 expression and mRNA PTEN were more likely to be associated with poor development and prognosis in breast cancer patients, in addition to their association with clinopathological and molecular status. Changes in miR-21 expression may be good candidates as a molecular prognostic marker for breast cancer progression, according to this report, and will contribute to the advancement of research, especially in the health and clinical fields. However, this study also has limitations in that it takes a long time at the qRT-PCR optimization stage to obtain the optimum temperature and time for the analysis of miR-21 and PTEN mRNA. In addition, the number of patient samples for advanced stages is less than the sample of patients in the early stages.

\section{CONCLUSION}

According to the findings of this study, miR-21 expression increased 1.32 times in the blood plasma of breast cancer patients at an advanced stage relative to the initial stage, while PTEN mRNA expression decreased 1.33 times. In terms of molecular status, there are variations in the expression levels of miR-21 and PTEN mRNA in breast cancer patients based on hormone receptors and subtypes. In future studies, it is necessary to conduct research related to the mechanism of interaction between miR-21 and mRNA PTEN in plasma / serum of breast cancer patients in terms of clinical and molecular status.

\section{CONFLICT OF INTEREST}

There were no conflicts of interest with related parties in this study.

\section{REFERENCE}

Andorfer, C. a., Necela, B. M., Thompson, E. A., \& Perez, E. a. (2011). MicroRNA signatures: Clinical biomarkers for the diagnosis and treatment of breast cancer. Trends in Molecular Medicine, 17(6), 313-319. https://doi.org/10.1016/j.molmed.2011.01.006

Anwar, S. L., Sari, D. N. I., Kartika, A. I., Fitria, M. S., Tanjung, D. S., Rakhmina, D., Wardana, T., Astuti, I., Haryana, S. M., \& Aryandono, T. (2019). Upregulation of circulating MiR-21 expression as a potential biomarker for therapeutic monitoring and clinical outcome in breast cancer. Asian Pacific Journal of Cancer Prevention, 20(4), 1223-1228. https://doi.org/10.31557/APJCP.2019.20.4.1223

Anwar, S. L., Tanjung, D. S., Fitria, M. S., Kartika, A. I., Sari, D. N. I., Rakhmina, D., Wardana, T., Astuti, I., Haryana, S. M., \& Aryandono, T. (2020). Dynamic Changes of Circulating Mir-155 Expression and the Potential Application as a Non-Invasive Biomarker in Breast Cancer. Asian Pacific Journal of Cancer Prevention : APJCP, 21(2), 491-497. https://doi.org/10.31557/APJCP.2020.21.2.491

Arroyo, J. D., Chevillet, J. R., Kroh, E. M., Ruf, I. K., Pritchard, C. C., Gibson, D. F., Mitchell, P. S., Bennett, C. F., Pogosova-Agadjanyan, E. L., Stirewalt, D. L., Tait, J. F., \& Tewari, M. (2011). Argonaute2 complexes carry a population of circulating microRNAs independent of vesicles in human plasma. Proceedings of the National Academy of Sciences of the United States of America, 108(12), 5003-5008. https://doi.org/10.1073/pnas.1019055108 
Chan, J. A., Krichevsky, A. M., \& Kosik, K. S. (2005). MicroRNA-21 is an antiapoptotic factor in human glioblastoma cells. Cancer Research, 65(14), 6029-6033. https://doi.org/10.1158/0008-5472.CAN-05-0137

Cheang, M. C. U., Chia, S. K., Voduc, D., Gao, D., Leung, S., Snider, J., Watson, M., Davies, S., Bernard, P. S., Parker, J. S., Perou, C. M., Ellis, M. J., \& Nielsen, T. O. (2009). Ki67 index, HER2 status, and prognosis of patients with luminal B breast cancer. Journal of the National Cancer Institute, 101(10), 736-750. https://doi.org/10.1093/jnci/djp082

Heneghan, H. M., Miller, N., \& Kerin, M. J. (2010). MiRNAs as biomarkers and therapeutic targets in cancer. Current Opinion in Pharmacology, 10(5), 543-550. https://doi.org/10.1016/j.coph.2010.05.010

Huang, G., Zhang, X., Guo, G., \& Huang, K. (2009). Clinical significance of miR-21 expression in breast cancer : of invasive ductal carcinoma. Oncology Reports, 21(2), 673-679. https://doi.org/10.3892/or

Li, L. Q., Li, X. L., Wang, L., Du, W. J., Guo, R., Liang, H. H., Liu, X., Liang, D. Sen, Lu, Y. J., Shan, H. L., \& Jiang, H. C. (2012). Matrine inhibits breast cancer growth via miR-21/PTEN/Akt pathway in MCF-7 cells. Cellular Physiology and Biochemistry, 30(3), 631-641. https://doi.org/10.1159/000341444

Li, M., Li, J., Ding, X., He, M., \& Cheng, S.-Y. (2010). microRNA and cancer. The AAPS Journal, 12(3), 309-317. https://doi.org/10.1208/s12248-010-9194-0

Lowery, A. J., Miller, N., Devaney, A., McNeill, R. E., Davoren, P. A., Lemetre, C., Benes, V., Schmidt, S., Blake, J., Ball, G., \& Kerin, M. J. (2009). MicroRNA signatures predict oestrogen receptor, progesterone receptor and HER2/neu receptor status in breast cancer. Breast Cancer Research, 11(3), 1-18. https://doi.org/10.1186/bcr2257

Meng, F., Henson, R., Wehbe-Janek, H., Ghoshal, K., Jacob, S. T., \& Patel, T. (2007). MicroRNA-21 regulates expression of the PTEN tumor suppressor gene in human hepatocellular cancer. Gastroenterology, 133(2), 647-658. https://doi.org/10.1053/j.gastro.2007.05.022

Mitchell, P. S., Parkin, R. K., Kroh, E. M., Fritz, B. R., Wyman, S. K., PogosovaAgadjanyan, E. L., Peterson, A., Noteboom, J., O'Briant, K. C., Allen, A., Lin, D. W., Urban, N., Drescher, C. W., Knudsen, B. S., Stirewalt, D. L., Gentleman, R., Vessella, R. L., Nelson, P. S., Martin, D. B., \& Tewari, M. (2008). Circulating microRNAs as stable blood-based markers for cancer detection. Proceedings of the National Academy of Sciences of the United States of America, 105(30), 10513-10518. https://doi.org/10.1073/pnas.0804549105

Mo, M.-H., Chen, L., Fu, Y., Wang, W., \& Fu, S. W. (2012). Cell-free Circulating miRNA Biomarkers in Cancer. Journal of Cancer, 3, 432-448. https://doi.org/10.7150/jca.4919

Negrini, M., \& Calin, G. A. (2008). Breast cancer metastasis: A microRNA story. Breast Cancer Research, 10(2), 2-5. https://doi.org/10.1186/bcr1867

Pan, X., Wang, Z. X., \& Wang, R. (2010). MicroRNA-21: A novel therapeutic target in human cancer. Cancer Biology and Therapy, 10(12), 1224-1232. https://doi.org/10.4161/cbt.10.12.14252

Radojicic, J., Zaravinos, A., Vrekoussis, T., Kafousi, M., Spandidos, D. A., \& Stathopoulos, E. N. (2011). MicroRNA expression analysis in triple-negative (ER, PR and Her2/neu) breast cancer. Cell Cycle, 10(3), 507-517. 
https://doi.org/10.4161/cc.10.3.14754

Schwarzenbach, H., Milde-Langosch, K., Steinbach, B., Müller, V., \& Pantel, K. (2012). Diagnostic potential of PTEN-targeting miR-214 in the blood of breast cancer patients. Breast Cancer Research and Treatment, 134(3), 933-941. https://doi.org/10.1007/s10549-012-1988-6

Song, M. S., Salmena, L., \& Pandolfi, P. P. (2012). The functions and regulation of the PTEN tumour suppressor. Nature Reviews. Molecular Cell Biology, 13(5), 283-296. https://doi.org/10.1038/nrm3330

Tran, B., \& Bedard, P. L. (2011). Luminal-B breast cancer and novel therapeutic targets. Breast Cancer Research, 13(6). https://doi.org/10.1186/bcr2904

Turchinovich, A., Weiz, L., Langheinz, A., \& Burwinkel, B. (2011). Characterization of extracellular circulating microRNA. Nucleic Acids Research, 39(16), 7223-7233. https://doi.org/10.1093/nar/gkr254

Wickramasinghe, N. S., Manavalan, T. T., Dougherty, S. M., Riggs, K. a., Li, Y., \& Klinge, C. M. (2009). Estradiol downregulates miR-21 expression and increases miR-21 target gene expression in MCF-7 breast cancer cells. Nucleic Acids Research, 37(8), 2584-2595. https://doi.org/10.1093/nar/gkp117

Yan, L.-X., Huang, X.-F., Shao, Q., Huang, M.-Y., Deng, L., Wu, Q.-L., Zeng, Y.-X., \& Shao, J.-Y. (2008). MicroRNA miR-21 overexpression in human breast cancer is associated with advanced clinical stage, lymph node metastasis and patient poor prognosis. RNA (New York, N.Y.), 14(11), 2348-2360. https://doi.org/10.1261/rna.1034808

Zhang, J., Wang, J., Zhao, F., Liu, Q., Jiang, K., \& Yang, G. (2010). MicroRNA-21 (miR21) represses tumor suppressor PTEN and promotes growth and invasion in nonsmall cell lung cancer (NSCLC). Clinica Chimica Acta; International Journal of Clinical Chemistry, 411(11-12), 846-852. https://doi.org/10.1016/j.cca.2010.02.074 